\title{
TOLERANCE AS CORE VALUE AND COMMUNICATION PRINCIPLE*
}

\author{
E.B. Minnullina** \\ Kazan State University of Power Engineering, Kazan, Republic of Tatarstan, Russia \\ E-mail: elinafil@mail.ru
}

\begin{abstract}
The purpose of this paper is to study the phenomenon of tolerance as an ethical and communication principle. There are some risks of appealing to tolerance. It can be argued that moral relativism does not allow for justification of norms of tolerance. One of the consequences of taking tolerance as the fundamental principle of interactions is that it can turn into a cultural separatism that alienates people. In total accord with the idea that relativistic tolerance makes criticism impossible, we would like to further develop the concept of tolerance and to consider a different angle. Relativistic interpretation of this notion leads to an ambiguous position, when tolerance does not lead to stabilizing relationships, but conditions separation between people, arbitrariness, and permissiveness, including admissibility of social injustice. We could call such kind of behavior a «seeming tolerance» that is replacing in reality the concepts of indifference and passive concession.
\end{abstract}

Keywords: rational tolerance; justice; communicative action; dialogue; moral principle.

Статья представляет собой расширенный вариант выступления на конференции - "8th LUMEN International Scientific Conference Rethinking Social Action. Core Values in Practice // RSACVP 2017 // 6-9 April 2017 // Suceava Romania"

\section{Introduction}

Tolerance is a topic of research in various spheres; its characteristics and principles are examined from the standpoint of social philosophy, ethics, political studies, sociology, cultural linguistics and other areas. Against the background of present-day social conflicts, and complex interethnic and interreligious relationships, this argumentative topic acquires special practical implications, especially the study of communicative aspects of tolerance. Communication is a condition under which the very relationship of tolerance becomes possible. Without establishing an interaction that allows people to identify certain points of contact and common sides, it is impossible to find a way out of the relationship of intolerance.

${ }^{*}$ Статья представляет собой расширенный вариант выступления на конференции "8th LUMEN International Scientific Conference Rethinking Social Action. Core Values in Practice // RSACVP 2017 // 6-9 April 2017 // Suceava - Romania”.

${ }^{* *}$ MINNULLINA Elina Borisovna - Doctor of Philosophy, Associate Professor, Department of Philosophy and Media Communication, Kazan State Power Engineering University. 
It should be noted at the very beginning that the semantics of tolerance has changed in the process of legal liberalization of relationships; the main sememe «legal order» joined the sense of a person's inner behavioral setup. At the moment, individual critical reflection is becoming a key attribute of tolerance, especially against the background of the expanding information space and the polylogical nature of communication that is inherent to this space. The New Philosophical Encyclopedia offers a fairly complete and profound definition:

«...tolerance, from Latin tolerantia, is a quality that characterizes such relation to another person as equally dignified, which is expressed in a conscious suppression of the feeling of rejection caused by all that marks them as different (appearance, manner of speech, tastes, lifestyle, beliefs, etc.). Tolerance implies willingness to understand and dialogue with the other, and recognition and respect for their right to be different» [9].

Agreeing with the basic formulation, we would like to add that tolerance denotes such type of relation to the other that requires not so much a deliberate suppression of the feeling of rejection as a reflexive intention to reach a consensus. In this sense, seeming tolerance that denotes a set of behavioral responses outside of the dialogue is different from true, rational tolerance. It is simultaneously the initial principle of communicative ethics (assuming focus on listening and readiness for dialogue as a two-way exchange of views) and the result of the dialogue, that is a discursive unity as the evolved quality of the relationship.

Rainer Forst, a modern German philosopher and one of the most influential theoreticians in the field of politics, takes the following for the initial premise to explain tolerance: «intolerance is a specific form of injustice, and toleration a demand of justice» [1]. This provision can serve as the basis for rationalizing the relationship that resides in a conscious suppression of rejection in relation to the other, and the starting point of goal-setting. A rational approach involves reflection and uncompromising criticism (including a review of one's own positions).

If we consider the concept of tolerance as a synonym for passive «suffering» (indeed, it is derived etymologically from Latin tolerare - carry out, endure, suffer), which implies a suppression of sensory responses - to compare with Russian терпеть [trrpet'] (to suffer, originating from the Latin torpeo - be torpid, stiff, stupefied), in such case the rational component is excluded from its semantics. Thereby, the objection, demonstrated in the active critical position, is an important condition of rational communication as the basis of tolerance. Thus, if this foundation is a mere set of sensory reactions, then it primarily implies a rational component of the relationship.

The task of this paper is to study tolerance primarily as a principle of discursive ethics that resides in a common aspiration to achieve mutual understanding and accord. For this, tolerance should be considered as an individual-personal disposition and a focus on communicative interaction. 


\section{Antinomies of Tolerance}

It is important to differentiate between seeming and rational tolerance, which is based on dialogical, mutual willingness to reach an agreement. That is to say, rational tolerance causes an effective interaction through reflection, mutual critical engagement, and mutual openness.

Tolerance is not indifference. Regarding the latter, the subject has neither significance nor differences for the individual. Tolerance is a deliberately, controllably restrained rejection. Karl Popper rightly argues: «It is so only in so far as he is capable of learning from criticism as well as from his own and other people's mistakes, and that one can learn in this sense only if one takes others and their arguments seriously. Rationalism is therefore bound up with the idea that the other fellow has a right to be heard, and to defend his arguments» [10].

From the point of view of natural human rights, tolerance is an ethical embodiment of this right - i.e. recognition of people's freedom to express themselves. One can pose a question about the necessity of forming tolerant relationships only on the border between two different ideological positions. It is becoming more and more articulate with the expansion of communicative space and growth of discursive differentiation. As a multifaceted phenomenon tolerance is antinomical. In order to establish tolerant relationships it is required to overcome contradictions: those of «reflection and discourse, both cognitive and behavioral, as well as of ethical and contextual norms» [1]. Thus, the specificity of tolerance is revealed in antinomies that manifest internal contradictions of communicative interaction.

Antinomy of reflection and discourse

A conflict of worldviews that poses the question of whether to be tolerant arises in conditions of discursive differentiation. Reflection that allows us to comprehend our place in the communicative space and find a way to understand the other may not be possible within the boundaries of the original discourse. The other's position and self-reflection in the discursive order, with respect to which tolerance should be formed, is unacceptable. Thus, the most difficult question is how the information character of interpersonal relations determines the reflexive mechanism. Theodor Adorno in his later works postulates that it is impossible to carry out a proper sense-critical distinction and reflection in conditions of mass society, because all these cognitive phenomena are nothing more than an instrumentalization of the mind. In the book Dialectics of Enlightenment T. Adorno and M. Horkheimer argue:

«The very concept of that thinking, no less than the concrete historical forms, the institutions of society with which it is intertwined, already contains the germ of the regression which is taking place everywhere today. If enlightenment does not assimilate reflection on this regressive moment, it seals its own fate» [4].

It would be possible to get out of this dead end and overcome this contradiction if there were a single criterion of the proper. Dialogue in this sense serves as a means of identifying points of contact, forming a discursive-reflexive unity that 
constitutes tolerant relations. The context of unity can be the lifeworld that is symbolically expressed in everyday communication.

The antinomy of the cognitive and behavioral

This contradiction becomes obvious when otherness is revealed not in the cognitive sphere, but in the practical domain. In this case, the divergence of viewpoints acquires political significance, and political decisions taken at the level of relationship management can be repressive. As it was emphasized, manifestation of tolerance, both group or individual, can only be discussed in the presence of cognitive discrepancies that are consciously accepted.

Conflict situations arise to a greater extent at the level of relations, in the practical behavioral sphere, even if discursively conditioned. «I know that this is bad, but I cannot do anything about it» - this reveals how rational tolerance is determined by irrationally overcoming oneself. Thus, it is possible to identify the differences between the tolerance of a representative of a religious denomination with respect to a dissident and that of a scientist who does not agree with the views of his colleague. This discrepancy is concerned with beliefs and arguments with which believers can support their position that is supposed to be rooted in their system of values and related to the notion of the good (where the good is their religion which governs people's behavior). Scientific discourse reflects a human desire for objective and impartial knowledge (for example, Max Weber posed a debatable question about freedom of empirical facts from the practical evaluation of the researcher [13]). The degree of discrepancy between opinions correlated with practice and ethical judgments is higher than in the case of those that are not concerned with values, since in the former case experiences of the world and the position of the Self and the other are differentiated.

It should be emphasized that understanding the principle of rational tolerance, ascending to the Socratic idea of the «culture» of intellect, is inseparable from interpreting the question of the interrelationship of truth, duty and good (in social practice orientation towards demand and prohibition or towards approval and condemnation). The leitmotif of the philosophical deontology of Modernity was cognitivism of critical philosophy, in which good was made dependent on duty. We believe that autonomization of morality determines isolation of the question of one's duty and goals from rationally-reflexive practice in specific historical conditions.

«It is restated for our time from a post-Kantian phenomenological perspective by Husserl and Heidegger, in the former's insistence on transcendental phenomenology as the defense of socially-indispensable reason and in the later Heidegger's claim that thinking beyond philosophy is equally indispensable» [11].

One way to solve the problem of autonomy of morality, followed by Jürgen Habermas, is the implication of the rational component of human behavior from communicative practice. This concept (also adopted by K.-O. Apel) is based on the strategy of constructing scientific and everyday communicative interaction on the 
basis of «argumentative discourse» as a search for the most significant argument. Actually, Kant too spoke of the conventional nature and general acceptance of moral laws [6], but his ethical correctness is analogous to the truth, and the universal significance of his imperative is not the result of communication. At the same time, if «crystallization» of the normative basis, carried out in practical discourse, did indeed lead to a conscious recognition by the participants in the dialogue (polylogue) of the community of experiences, then the formulation of the problem of intolerant relations would be excessive. However, the issue on the agenda is how much one is free to consciously recognize the difference.

Thus, the contradiction between knowledge and behavior in tolerance manifests the question of the relationship between the general and the private, the social and the individual in discourse. Morality performs functions of a social institution that warns and protects individuals who are forced to coordinate their actions with the law and, for example, religious morality that comes into conflict with them. «Hence the greatest crimes have been found, in many instances, compatible with a superstitious piety and devotion» [5]. Norms and principles that perform a prohibitive and protective function are realized in communication and are not confronted by themselves, but in communication: anthropocentrism and theocentrism can act as polar concepts, or can complement each other depending on the specific speech at issue. At the same time, tolerance as a communication principle highlights the degree of individual freedom.

In the communicative space, the process of people's acquisition of the qualities that are significant in the social aspect, as well as their entry into social groups, which is a part of social integration, is not only their gradual inclusion in the relations of subordination and domination (this is the negative function of individualization noted by Michel Foucault in the preface to «Anti-Oedipus»), but also the process of communication and, accordingly, the process of focusing on mutual interpretation. It is worth noting that the classical critical theory saw integration as a mechanism for non-violent suppression of freedoms. At the same time, in the context of postsecular society [3], another aspect of integration is of particular importance - that of solidarity, shared responsibility, and adoption of a different order and culture.

In their work «Religious Arguments in the Public Sphere: Comparing Habermas with Rawls», Belgian philosophers and specialists in social and political theory P. Loobuyck and S. Rummens write:

«In this postsecular context, a peaceful coexistence of religious and secular citizens in a democratic constitutional state requires, Habermas argues, a complementary learning process. Orthodox religious traditions should become reflexive in the sense that religious citizens should find ways to reconcile their own religious beliefs with respect for the freedom of religion of others, with the acknowledgment of the independent validity of scientific knowledge as well as with the secular character of the constitutional state» [7].

The problem of constituting an objective moral order, urged by the representatives of the late Frankfurt School, as well as joint responsibility and recognition of the free- 
dom of others, is that communicative action at a particular historical moment can conflict, taking into account lack of correlation between the discursive units.

The antinomy of the formal procedure (norms of discourse ethics) and context

In the format of the post-metaphysical «turn», the central question of practical philosophy «What should I do?» can be expressed in the framework of the theory of social communication: «How should I treat others in my actions?». The difficulty of clearly articulating the normative principles of the discourse that is determined by the intention for mutual accord is that, firstly, one convention may contradict another, and secondly, the rationality of norms is conditioned by the historical context. If the normative communicative action, which has its basis in the actors' desire to achieve mutual accord, is understood as a guarantee that they will come to this accord, then the entire existential context of individual experiences is excluded from social communication. On the other hand, intersubjectivity, which takes the place of the Kantian subject with the interrogative «What should I do?», is an eventful pre-consensual formation of semantic identities (Heidegger's precepts) in the joint experience of the world and its symbolic fixation in everyday communicative practice against the backdrop of discursive differentiations.

The ability to step back from a single point of view and to hear the other can be called a characteristic of communicative rationality that reflects an actor's competence. It should be noted that in the theory of communicative action, this ability to use knowledge in speech (and the ability to produce «validity claims») does not refer to the qualities of knowledge itself.

\section{Tolerance in Tatarstan}

A constructive form of tolerance can be demonstrated by the example of relationships between Tatar and Russian people in Tatarstan. Whereas in many Western countries their numbers are growing, all too often Muslims in those countries find themselves isolated geographically and culturally. The situation in Tatarstan is quite different. There, for hundreds of years, Muslims and Christians have lived together peacefully, churches and mosques standing side by side, and over $30 \%$ of marriages crossing religious and ethnic lines [12]. Mere proximity cannot explain such non-violent coexistence, for there are many societies where proximity between different religious and ethnic groups does not lead to peace.

Several factors contribute to religious harmony in Tatarstan.

One is a consistent commitment to centrist public policy and criticism of extremism from media and political figures as well as cultural leaders. In such political measures we can see the purview of tolerance: it lies between the boundary of what one objects to but can accept and that of strict rejection (let us say extremism). The rationality of tolerance implies that the realm of acceptance has to be common and more evident than that of rejection. Rais Suleymanov, Head of the center of the Volga Regional and Ethno-Religious Studies of the Russian Institute of Strategic Studies (RISS) argues that there are criteria of an objective Islamic situation in any region, for exam- 
ple in Tatarstan. When it comes to Islamic fundamentalists, there is another element acts of terrorism. There is a legislative instrument to maintain the boundary between toleration and rejection (extremism): according to the amendments to the local Law on Religious Organizations (August 2012) all Heads of official Islamic organizations have the right to set their own qualification requirements for employees, such as having a Russian Muslim education.

Another necessary point of tolerance in Tatarstan is the formation of Tatar ethnic and national consciousness that incorporates Islamic and Christian influences but also a commitment to a universal discursive space including Russian and Western European identity as well. This discursive space permits the practice of everyday, mundane communicative situations guided by a respect for otherness and difference. On the other hand, conflicts between residents and immigrants (e.g. Tajics) in Tatarstan can occur. This picture is typical for today's multicultural space, where Tatarstan is not an exception.

Third is an enduring commitment to interreligious dialogue. Reflecting upon the nature of this dialogue, we intend to consider situations in which an effective dialogue requires mutual critical engagement.

First of all, there are several necessary components of the rational tolerant attitude: context, reflection and critical dialogue, objection, acceptance, and purpose. The main component of rational tolerance is objection; in other words, actions of the person (group, institute) being tolerated are considered as wrong, bad, or unacceptable. If the nature of tolerance were based on connivance without criticism («do what you want», «live and let live»), in that case there would be no need to endure anything. Thus, criticism is a necessary part of tolerance: if you tolerate something that means that you reject something, and therefore endure and criticize it. Tolerance presupposes a motivation to criticize. Of course, the nature of objections can differ and they can depend on how correct the state politics in the interreligious (interethnic) sphere is. This is connected with the problem that the policy of a region can often use seeming tolerance as an instrument of dominance and suppression. In that case an idea (a concept) of tolerance becomes a means of manipulation. As we understand, the purpose of calling for tolerance should be harmony and peace in a region and not furtherance of someone's political interests.

In social practice, the most significant issue is to establish the boundaries of tolerance within which it can be necessary and corresponding to the nature of interpersonal interaction. The primary task in this case is to identify the quality of the relationship and the possible substitution of concepts, where indifference becomes the referent of the concept under consideration. Intentionally concealing acute problems, avoiding a responsible decision, is not identical with tolerance. The discursive essence of tolerance can be revealed by analyzing speech acts, which allows us to highlight the illocutionary aspect (purpose and motive) of speech relations. It is necessary to proceed from the premise that tolerance is possible only in a dialogue when discursive heterogeneity 
is the basis for understanding the conflicting sides, and the claims of the significance of their arguments do not lead to an agreement on the subject, but to a conscious acceptance of a different point of view.

Communication between different cultures in Tatarstan is realized in similar fashion. But the situation becomes more complicated when «the other side» can challenge and this fact becomes politically significant. In the context of Arabian revolutions the question of Islamic fundamentalism expansion in Russia becomes topical and Tatarstan as a Republic of Muslims is under special scrutiny. The relations inside Islam itself are now more topical (and evidently having a political color) than between Islam and Christianity. As Hazrat Valliullah Yakupov, a famous Tatarstani religious and public figure said during a conference:

«We have interreligious dialogue, but we do not set goals to achieve theological advantages. If we abandon the goal to convince someone of something, we can work together. Though the theological difference will never be overcome» [1].

We believe this is pretty much what Habermas said about tolerance in Between Naturalism and Religion. In order to be tolerant, you initially have to completely disagree. There is an answer of Patriarch Sergius to that (quite expected though): «If we stick to the golden middle, there can be no war» [reference].

Another important component of tolerance is context. The context of interethnic and interreligious relations in Tatarstan has been changing during four centuries after the conquest of Kazan by Ivan the Terrible, and has influenced the characteristics of tolerance; thus, in the sixteenth through eighteenth centuries Islam and its religious institutions were not prohibited; moreover, against the background of political games and mutual Russian-Tatar intrigues Muslim princes (e.g. from the Kasimov Kingdom) played a prominent role in the political life of the Russian state. In general it can be argued that tolerance has been formed as a basis of politically advantageous discourse illustrated by the fact of the Decree of Catherine II on the Tolerance of All Religions in 1773. Thus, context forms a discursive unit that contributes to gradual alignment and harmonization of relations and gradually abolishes the need for tolerance.

It can seem that universal norms could serve as some kind of limit for tolerance but at present, globalization is rapidly destroying the «normal» context of coexistence. The solution is to develop ethical norms of the dialogue, the central element of which is legitimating peaceful dialogical conflict and a refusal to suppress it by imposing authoritarian orders.

The problem of differences between believers and non-believers is not causing so many conflicts, but is no less relevant. In a secular society, different discourses are confronted, while the public sphere reveals an asymmetry of their social significance: secular discourse is clearly dominant. If believers enter into a public discussion, they have to refer to the arguments of a different discourse. So, in the postSoviet era, Islam sought to regain its lost ground, and the increased number of Muslims could not but evoke a certain response among atheistically-minded citizens, appealing to the traditions of the Tatar people. It should be noted that the dia- 
logue which forms the common border of tolerance does not necessarily lead to interpreting alien rationality nor to forming the only true universal formula for communication; at this point, however, each of the participants can disclose for themselves the sacral meaning of the profane and the secular significance of the sacred. It is noteworthy that the majority of Muslims in Tatarstan profess traditional Islam (the Hanafi madhhab), therefore at the heart of dialogue between the confessions there are general discursive and ideological positions.

Being explicit at the boundaries between different worlds, tolerance has not only a legal foundation (in terms of the UNESCO's Declaration of Principles on Tolerance, 1995), but in the context of the growing communication space and legal liberalization it has also an individual meaning, the value of personal behavior and disposition. Hence, in Tatarstan marriages between Muslim and Christian are typi$\mathrm{cal}$, and it is a task of people themselves not to allow religious differences to destroy personal relationships. On the other hand, the personal level of relations cannot exist beyond the social and political sphere. Last year the activists of the Society of Russian Culture (ORK) of Tatarstan boycotted the celebration of International Day for Tolerance, on 16 November, and explained it by discriminatory policies of local authorities. Of course, some political steps and actions can be followed by social resonance. A primary solution is to hold the centrist public policy and to keep tolerant atmosphere. Reflecting on the principles and limits of tolerance, Habermas appeals to the following thought of Charles De Montesquieu: «As soon as some countries came to the laws on accepting many religions, they had to oblige them to demonstrate mutual tolerance» [2]. So, tolerance in mutual critical dialogue is a personal disposition. And it is obvious that there is a higher moral order that limits tolerance and is the solution of paradoxes of tolerance [1].

\section{Conclusions}

We have come to an important idea that tolerance is possible only in conditions of community preparedness for tolerance. It is important to define the boundary between what can be tolerated and what cannot. In the context of the Tatarstan situation it is obvious that we can endure the difference of ideas in cultural and religious realms to reject everything connected with injustice and disturbing peace and harmony.

It can be presumed that the key element in the structure of tolerance as a principle of discourse ethics should be the assumption of the existence of a difference. Tolerance includes objections. Moreover, tolerance cannot be founded on refraining from moral judgments «in the name of tolerance». This is a paradox of tolerance: how to be tolerant and not to be immoral. The decision is to find a criterion of a higher level, formulating generally significant values, such as justice. Justice is a basis of the legal component of tolerance and the foundation of social stability.

\section{References}


1. Forst R. The limits of Toleration. Constellations. - September 2004. - Vol. 11. - Issue $3 .-317 \mathrm{p}$.

2. Habermas J. Wann müssen wir tolerant sein? Über die Konkurrenz von Weltbildern, Werten und Theorien, lecture at Leibniz Conference, berlin, 29.6.2002. in "Jahrbuch 2002, Berlin-Brandenburgische Akademie der Wissenschaften", Akademie, 2003, pp. 167-178, (tr. en. When Must We Be Tolerant? On Competing World Views, Values and Theories, Lecture at Loyola University of Chicago, Rationality and Universalism: A Dialogue Between Richard Rorty and Jürgen Habermas, 1.11.2002). - P. 167.

3. Habermas J. What is Meant by a Post-Secular Society? In Europe: Faltering Project. Cambridge: Polity Press; - 2009. - P. 59.

4. Horkheimer M., Adorno T. Dialectic of Enlightment. Philosophical Fragments. Ed. by Gunzelin Schmid Noerr. Stanford, California: Stanford University Press; - 2002. - P. XVI.

5. Hume D. The Natural History of Religion. Stanford University Press. Stanford, California. - 1957. - P. 72.

6. Kant I. Critic of practical reason. Hackett Publishing Company, Inc. Indianapolis/Cambridge. - 2002. - P3. 45-48.

7. Loobuyck P., Rummens S. Religious Arguments in the Public Sphere: Comparing Habermas with Rawls. Ars Disputandi Supplement 5; 2011. - P. 237-239.

8. Minnullina E.B. Ratsionalnaya Tolerantnost Kak Printsip Etiki Diskursa. Teoriya i praktika obschestvennogo razvitiya. - 2013. - № 9. - Pp. 27-32.

9. Novaya filosofskaya entsiklopediya: T. IV. - M.: Myisl, 2010. - Pp. 75-76.

10. Popper K. The Open Society and Its Enemies. Volume II. The high tide of prophecy: Hegel, Marx, and the Aftermath. London: Great Britain by Butler \& Tanner Ltd.; 2009. - P. 225.

11. Rockmore T. More Hegelian Doubts about Discourse Ethics. In The ethics of Postmodernity. Current trends in Continental Thought. Evanston, Illinois: Northwestern University Press; 1999. - P. 57.

12. Vavilova Zh., Broadbent J. T. Bilingual Identity: Issues of Self-Identification of Bilinguals in Malaysia and Tatarstan. 3L: The Southeast Asian Journal of English Language Studies. - Vol 21(3). - Pp. 141-150.

13. Weber M. The Methodology of the Social Sciences. The Free Press of Glencoe, Illinois. -1949 . - P. 1 .

\section{ТОЛЕРАНТНОСТЬ КАК ОСНОВНАЯ ЦЕННОСТЬ И ПРИНЦИП КОММУНИКАЦИИ}

\section{Э.Б. Миннуллина*}

Казанский государственный энергетический университет, Казань, Республика Татарстан, Россия

E-mail: elinafil@mail.ru

*МИННУЛЛИНА Элина Борисовна - доктор философских наук, доцент, заведующая кафедрой философии и медиакоммуникации ФГБОУ ВО «Казанский государственный энергетический университет». 
Аннотация. Целью данной работь является изучение феномена толерантности как этико-коммуникативного принципа. В обращении к толерантности есть определенный риск. Можно утверждать, что моральный релятивизм не допускает обоснования норм толерантности. Одним из последствий принятия толерантности в качестве основополагающего принциипа взаимодействия является то, что она может превратиться в культурный сепаратизм, отчуждающий людей. В полном согласии с мыслью о том, что релятивистская толерантность делает критику невозможной, мь хотели бы продолжить развитие концепции толерантности и рассмотреть ее под другим углом. Релятивистская трактовка этого понятия приводит к неоднозначной позищии, когда толерантность не приводит к стабилизации отношений, а обусловливает разделение людей, произвол и вседозволенность, в том числе допустимость сочиильной несправедливости. Такое поведение можно было бы назвать «кажущейся терпимостью», заменяющей в действительности понятия безразличия и пассивной уступчивости.

Ключевые слова: рациональная толерантность; справедливость; коммуникативное действие; диалог; нравственный принцип. 